\title{
PPM PELATIHAN REGULASI EMOSI BAGI KELOMPOK IBU PKK TERDAMPAK COVID-19 DI KALIMLOM LOR BARU SURABAYA
}

\author{
Aironi Zuroida ${ }^{1}$, Firsty Oktaria Grahani ${ }^{2}$, Yohanes Rivaldo Kalu Menang ${ }^{3}$, Indah Dwi \\ Suryaningsih $^{4}$ \\ ${ }^{1}$ Universitas Wijaya Putra \\ ${ }^{2}$ Universitas Wijaya Putra \\ ${ }^{3}$ Universitas Wijaya Putra \\ ${ }^{4}$ Universitas Wijaya Putra
}

aironizuroida@uwp.ac.id, oktaria@uwp.ac.id, menangrhifal@gmail.com, 18081008@uwp.ac.id

\begin{abstract}
Abstrak
Wabah corona virus (covid-19) menimbulkan berbagai masalah psikologis dan konsekuensi penting dari segi kesehatan mental. Masa pandemi ini membuat ibu rumah tangga memiliki peran ganda dan beban yang berlebih akibat diberlakukannya kebijakan selama pandemi ini, termasuk ibu rumah tangga yang tergabung dalam PKK RT.04 Kalilom Lor Baru Surabaya. Pandemi covid-19 ini dirasakan oleh kelompok ibu PKK RT.04 memiliki dampak yang cukup besar. Dari segi sosial tidak adanya kegiatan berkumpul dengan anggota yag lain selama masa pandemi membuat mereka semakin jenuh menjalankan kegiatan sehari-hari. Dari segi kesehatan, banyaknya tuntutan Ibu untuk bisa mengatur perputaran ekonomi keluarga agar kondisi ekonomi keluarga tidak terganggu, mengurus rumah tangga dan mengawasi anak yang belajar online di rumah. Permasalahanpermasalahan tersebut memunculkan emosi-emosi negatif pada ibu rumah tangga, sehingga membuat ibu kurang bisa mengontrol emosi dalam mengasuh anak. Tujuan pengabdian ini ibu PKK memiliki kemampuan regulasi emosi sehingga dapat meminimalisir munculnya emosi negatif dalam diri. Metode pelaksanaannya melalui psikoedukasi, pelatihan kepada anggota kelompok ibu PKK cara mengekspresikan emosi, mengelola emosi dan mengubah emosi negatif menjadi emosi positif. Hasil dari pengabdian ini, ibu PKK mulai mampu mengenali emosi dalam diri serta mampu mengelola emosi negatif yang dirasakan.
\end{abstract}

Kata Kunci : Pemberdayaan Kelompok ibu PKK, regulasi emosi, Covid-19.

\section{PENDAHULUAN}

Terjadinya wabah corona virus (covid-19) sudah lebih dari satu tahun telah meluluhlantakkan dunia. Penetapan Covid-19 sebagai pandemi global telah dinyatakan oleh World Health Organization (WHO) pada 9 Maret 2020. Data menunjukkan jumlah orang yang terinfeksi terus meningkat dan mencapai jutaan orang dengan angka kematian yang juga sangat tinggi. Selain berdampak pada kesehatan dan dapat mengakibatkan kematian, wabah virus Covid 19 juga berdampak pada kesehatan mental atau kesejahteraan psikologis manusia (Othman, 2020). Berbagai masalah psikologis dan konsekuensi penting dari segi kesehatan mental seperti stres, kecemasan, depresi, 
frustasi, ketidakpastian saat wabah Covid-19 semakin bermunculan.

Berdasarkan hasil wawancara dengan kelompok ibu PKK RT.04 RW.08 Kalilom Lor baru, diperoleh informasi bahwa para anggota kelompok ibu PKK merasakan munculnya permasalahan yang ada pada diri mereka selama pandemi ini. Anggota ibu PKK yang terdiri dari ibu rumah tangga belum siap dan menjadi kesulitan dalam mendampingi proses belajar anak karena adanya perubahan sistem pendidikan dari pembelajaran offline menjadi online. Dengan adanya pembelajaran online, ibu rumah tangga yang tergabung dalam kelompok PKK menjadi lebih tertekan karena dituntut ekstra untuk melakukan pendampingan terutama saat anak harus diberi penjelasan mendetail berkaitan materi dan tugastugas yang diberikan oleh sekolah, sedangkan mereka merasa kurang bisa menguasai materi tersebut dikarenakan latar belakang pendidikan yang kurang memadai.

Ibu rumah tangga khususnya yang tergabung dalam PKK RT.04 Kalilom Lor Baru Surabaya memiliki peran ganda dan beban yang berlebih akibat diberlakukannya kebijakan selama pandemi covid-19. Ibu dituntut untuk bekerja agar kondisi ekonomi keluarga tidak terganggu, mengurus rumah tangga dan mengawasi anak yang belajar online di rumah. Permasalahanpermasalahan tersebut menimbulkan emosi negatif pada ibu rumah tangga. Menurut Yuliani (2013), emosi negatif merupakan perasaan kurang menyenangkan yang dialami oleh individu yang mempengaruhi bagaimana individu bersosialisasi dengan orang lain. Emosi negatif yang dirasakan anggota kelompok ibu PKK seperti mudah kesal, sedih, marah, cemas, lelah, tidak bersemangat dan bentuk emosi lain yang dapat berubah secara tibatiba. Untuk bisa melaksanakan begitu banyak tugas dalam waktu bersamaan tentu sangat sulit dan menuntut kemampuan untuk meregulasi emosi dengan baik. Regulasi emosi yang tepat akan dapat menciptakan ketenangan sehingga pekerjaan ibu rumah tangga dapat terselesaikan dengan baik (Marliani, Nasrudin, Rahmawati, \& Ramdani, 2020). Ibu yang memiliki regulasi emosi yang baik akan memiliki kesejahteraan subjektif yang juga baik (Marliani, dkk, 2020). Disaat seperti ini, kemampuan regulasi emosi sangat dibutuhkan untuk menghindari adanya mental illness dan menurunnya sistem kekebalan tubuh yang dapat menyebabkan individu lebih mudah terkena Covid19.

PKK atau Pemberdayaan Kesejahteraan Keluarga sebagai salah satu organisasi masyarakat yang tumbuh dari bawah dengan wanita sebagai penggeraknya mempunyai peranan strategis dalam pencapaian tujuan pembangunan nasional. Sejak dicanangkan Tahun 1984 berdasarkan Keputusan Menteri Dalam Negeri No. 28 Tahun 1984 hingga kini PKK telah memberikan kontribusi yang nyata bagi keberhasilan $\mathrm{KB}$, sehingga program untuk menekan angka pertumbuhan penduduk dapat tercapai. Demikian juga peranan PKK dalam mewujudkan keluarga sehat sejahtera melalui Posyandu, PMT, UPGK, Imunisasi, dan lain-lain telah nyata hasilnya (Rantung et al., 2014). Namun, ke depan PKK harus dapat merubah paradigma lama yang kadang menjemukan. Kegiatan - kegiatan yang terkesan bersifat otoritas, sampai ke bawah kurang memberdayakan potensi masyarakat. Karena itu, sesuai tuntutan zaman perlu adanya paradigma baru. PKK di masa depan hendaknya lebih kooperatif, demokratif, memberdayakan keluarga untuk meningkatkan kesejahteraan menuju terwujudnya tujuan gerakan PKK (Onny Siagian, 2020).

Berdasarkan hasil pengamatan yang dilakukan terhadap kelompok ibu PKK di Rt.04 Rw.08 Kalilom Lor Baru Surabaya, dapat dikualifikasikan dalam dua aspek yakni aspek kognitif dan aspek afeksi. Pada aspek kognitif, adalah minimnya pemahaman pada kelompok ibu PKK akan pentingnya pengelolaan emosi dan pengetahuan terkait teknik-teknik dalam meregulasi emosi. Sedangkan pada aspek afeksi belum adanya pembekalan khusus semacam pelatihan yang dilakukan terhadap kelompok ibu PKK dalam membantu masyarakat mencegah munculnya emosiemosi negatif yang tidak tertangani dengan baik dan jika muncul emosi negatif pada ibu rumah tangga seperti membentak ataupun menyakiti anak, atau kurangnya kemampuan interaksi yang sehat baik dengan keluarga maupun warga sekitar, maka 
masyarakat cenderung mengangkapnya sebagai hal biasa.

Salah satu upaya yang dapat dilakukan untuk dapat mengelola emosi dengan tepat adalah dengan melakukan pelatihan regulasi emosi. Pelatihan regulasi emosi diharapkan dapat mengatasi permasalahan dalam mengelola emosi-emosi negatif yang dimiliki oleh kelompok ibu PKK RT.04 Kalilom Lor Baru Surabaya selama masa pandemi Covid-19. Sehingga diharapkan kedepannya dapat mengelola emosi negatif yang ada pada dirinya dapat dapat berinteraksi dengan baik pada lingkungan sekitarnya, dan dapat mengorganisir pekerjaan rumah tangga dengan lebih baik termasuk dalam merawat anak-anak mereka. Tujuan dari pengabdian ini adalah untuk meningkatkan pengetahuan dan pemahaman kelompok ibu PKK RT.04 mengenai regulasi emosi. Serta meningkatkan keterampilan regulasi emosi negatif yang dialami kelompok ibu PKK selama masa pandemi.

\section{METODE}

Metode pelaksanaan kegiatan pengabdian kepada masyarakat yang berupa pelatihan regulasi emosi meliputi tahapan-tahapan berikut :

1. Melakukan pengukuran untuk mengetahui pemahaman terkait regulasi emosi ibu rumah tangga di kalilom lor baru Rt.04. Rw.08 melalui kuesioner sebagai bahan untuk membuat baseline.

2. Melakukan koordinasi dengan mitra terkait jadwal pelaksanaan pelatihan serta memastikan peserta dari kelompok ibu-ibu PKK yang dapat mengikuti pelatihan.

3. Menyusun program pelatihan yang akan dilakukan berkaitan dengan regulasi emosi dengan rangkaian sebagai beriku : Pelaksanaan pelatihan regulasi emosi dibagi menjadi dua tahap. Tahap pertama terdiri dari dua sesi, sesi pertama yakni pemberian materi mengenal emosi dan mengekspresikan emosi. Sesi kedua materi mengelola emosi. Sedangkan pada tahap kedua sesi pertama adalah pelatihan berupa mengubah emosi negatif menjadi emosi positif dan sesi kedua pelatihan menenangkan diri.
4. Menyusun modul pelatihan regulasi emosi yang digunakan selama proses pelatihan berlangsung dan selanjutnya dapat digunakan sebagai salah satu bentuk panduan dalam mengelola emosi, sehingga diharapkan setelah adanya pelatihan dapat mempermudah ibu rumah tangga menerapkan regulasi emosi dalam kehidupan sehari-hari.

5. Evaluasi hasil pelatihan : Hasil kuesioner sebelum dan sesudah pelatihan diolah dan dianalisa sehingga dapat diketahui apakah program pelatihan memiliki hasil yang sesuai dengan target yang diharapkan.

\section{HASIL DAN PEMBAHASAN}

Kegiatan pengabdian masyarakat ini telah dilaksanakan pada bulan Juli 2021. Pelatihan dilaksanakan dua tahap dan setiap tahapan berlangsung dua sesi. Peserta dalam pelatihan ini adalah ibu-ibu kelompok PKK kalilom lor baru Rt.04. Rw.08. Pelaksanaan pelatihan dilaksanakan bertempat di salah satu rumah peserta. Selama pelaksanaan pelatihan berlangsung, peserta pelatihan cukup kooperatif dan aktif mengajukan pertanyaan apabila kurang memahami isi dari materi serta aktif mengikuti tahapan-tahapan dalam pelatihan.

Pada pelatihan tahap pertama, sesi pertama yang membahas tentang definisi emosi dan bagaimana cara meng ekspresikan emosi, peserta nampak antusias dan beberapa peserta mengaku baru memahami bahwa bentuk emosi tidak hanya marah, namun bahagia juga bagian dari emosi. Pada sesi kedua yakni sesi mengelola emosi, peserta diajak untuk menyadari adanya perasaan-perasaan negatif dan menuliskannya, serta merasionalisasikan perasaan tersebut sehingga perasaan dapat dijelaskan secara rasional atau logis. Hal ini dapat dilakukan dengan mengetahui sebab dan akibat kemunculan emosi negatif yang ada.

Pelatihan tahap kedua, pada sesi pertama dengan tema mengubah emosi negatif menjadi emosi positif, peserta diminta untuk menulis emosiemosi negatif yang dirasakan diatas tas canvas, kemudian tulisan tersebut di hapu denganmenggunakan cat warna-warni dan diatasnya diganti dengan tulisan penyemangat diri. Pada sesi 
ini para peserta merasa sangat senang karena bisa merubah emosi negatif menjadi emosi positif dan bisa membuat karya dari perasaan tersebut. Selanjutnya pada sesi kedua sesi menenangkan diri, Peserta diminta untuk mengambil posisi senyaman mungkin. Peserta diminta untuk memejamkan mata, menarik nafas melalui hidung dan menghitung 123 4, kemudian menahan nafas dan menghitung 123 4, selanjutnya melepaskannya lewat mulut dan

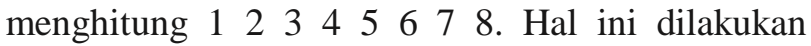
minimal 3x. Peserta diajak untuk mengingat kembali peristiwa menyenangkan atau membahagiakan yang pernah dirasakan. Dan dilanjutkan dengan mengucapkan kalimat-kalimat positif dan syukur sebanyak-banyaknya.

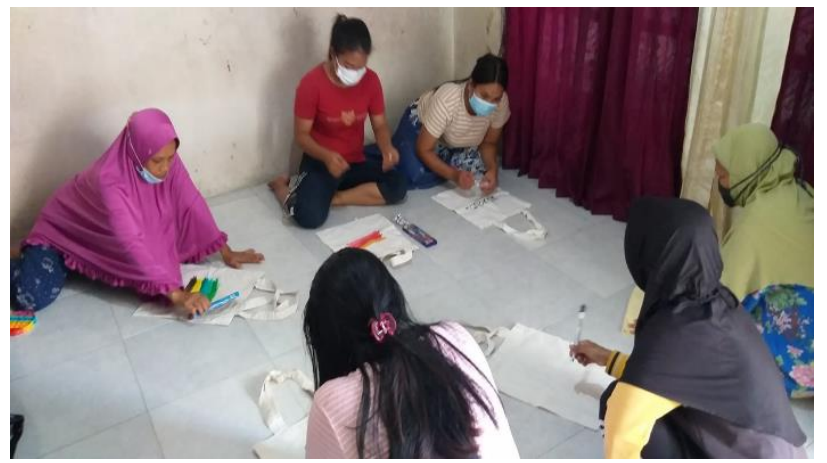

Gambar 1. Pelatihan Regulasi emosi dengan materi "Mengubah emosi Negatif menjadi emosi positif"

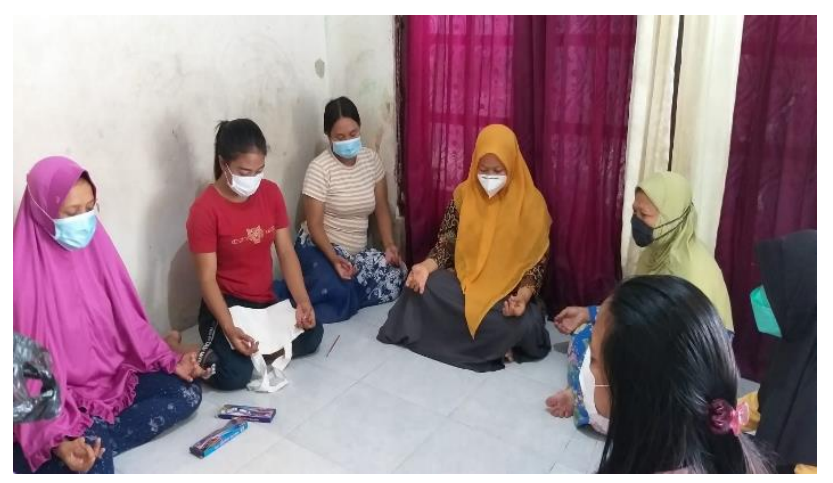

Gambar 2. Pelatihan Regulasi emosi dengan materi "Menenangkan Diri"

Setelah satu minggu dilaksanakannya pelatihan regulasi emosi tahap kedua maka para peserta diberikan kuesioner yang berisi pertanyaan mengenai regulasi emosi. Dari hasil kuesioner tersebut diketahui bahwa, pada aspek kognitif peserta telah dapat mengetahui tentang emosi dan dapat mengidentifikasi emosi yang dirasakan serta dapat menenangkan diri secara mandiri, para peserta juga sudah mulai memahami pentingnya regulasi emosi dalam diri. Sedangkan pada spek afeksi peserta mulai dapat mengidentifikasi emosi yang dirasakan serta dapat menenangkan diri secara mandiri, sehingga saat timbul emosi negatif dalam diri, mereka mulai mampu menenangkan diri dan dapat meminimalisir perasaan-perasaan negatif yang muncul. Para peserta juga bersemangat untuk mengajarkan pada ibu-ibu kelompok pkk yang lain bagaimana cara meregulasi emosi dalam diri dengan menggunakan modul yang telah didapat saat pelatihan.

Dari hasil kegiatan pengabdian masyarakat yang telah dilakukan sebelumnya juga telah dibuktikan bahwa pelatihan regulasi emosi memberikan efek yang cukup optimal terutama terkait pengendalian emosi pada peserta pelatihan. Hasil pelatihan regulasi emosi ini didukung oleh pelatihan yang dilakukan Olievia Prabandini Mulyana, dkk. (2020) berjudul pelatihan regulasi emosi untuk meningkatkan strategi regulasi emosi pada mahasiswa psikologi FIP Unesa yang terdampak covid-19 menunjukkan bahwa intervensi berupa pelatihan regulasi emosi memberikan pengaruh yang cukup signifikan bagi partisipan. Regulasi emosi juga memiliki pengaruh positif terhadap penerimaan diri pada anak (Rani Handri Yanti, dkk. 2019)

\section{KESIMPULAN}

Pengabdian kepada masyarakat ini bertujuan untuk meningkatkan pengetahuan dan pemahaman kelompok ibu PKK mengenai regulasi emosi. Serta meningkatkan keterampilan regulasi emosi negatif yang dialami kelompok ibu PKK terutama selama masa pandemi. Hal ini dikarenakan banyaknya permasalahan yang dialami oleh kelompok ibu PKK baik dalam proses pendampingan sekolah online anak-anak maupun permasalahan ekonomi yang terdampak karena pandemi. Oleh karena itu perlu adanya pelatihan untuk meningkatkan kemampuannya dalam regulasi emosi mereka. 
Melalui pengabdian kepada masyarakat ini dapat diketahui bahwa pelatihan regulasi emosi yang diberikan telah dapat membantu kelompok ibu PKK menjadi lebih optimal dalam mengelola terutama emosi negatifnya dan meningkatkan keterampilan partisipan dalam meregulasi emosi. Dan dengan adanya modul yang diberikan kepada peserta memudahkan mereka dalam mempraktikan regulasi emosi dalam kehidupan sehari-hari. Dengan modul tersebut pula peserta diharapkan dapat menjadi kader bagi anggota kelompok ibu PKK yang lain untuk membuat maupun memberikan penyuluhan terkait regulasi emosi.

\section{UCAPAN TERIMAKASIH}

Ucapan terimakasih disampaikan kepada kelompok ibu PKK RT.04 RW.08 Kalilom Lor baru khususnya kelompok ibu PKK yang terlibat sebagai peserta dalam program pelatihan regulasi emosi kelompok ibu PKK yang terdapat covid-19 atas kontribusi dan kerjasamanya selaku mitra.

Ucapan terimakasih disampaikan juga kepada Fakultas Psikologi Universitas Wijaya Putra dan LPPM atas dukungannya sehingga kegiatan ini dapat terlaksana dengan baik.

\section{REFERENSI}

Kamal, N. M. and Othman, N. (2020) „Depression, Anxiety, and Stress in the time of COVID-19 Pandemic in Kurdistan Region, Iraq ${ }^{\text {ee }}$, Kurdistan Journal of Applied Research. doi: 10.24017/covid.5.

Marliani, R., Nasrudin, E., Rahmawati, R., \& Ramdani, Z. (2020). "Regulasi emosi, stres, dan kesejahteraan psikologis: Studi pada ibu work from home dalam menghadapi pandemi COVID-19". Karya Tulis Ilmiah LP2M UIN SGD Bandung.

Mulayan, O.P, dkk (2020) "Pelatihan Regulasi Emosi untuk Meningkatkan Strategi Regulasi Emosi pada Mahasiswa Psikologi FIP Unesa yang Terdampak Pandemi Covid-19". JURPIKAT; Jurnal Pengabidan Kepada Masyarakat. Vol.1. No. 3; 249-261

Onny Siagian, A. (2020). "Character Building Relasi Dalam Kehidupan Beragama Dan Bersosial" (V. Meilinda \& A. S. Wijaya (eds.)). Syntax Computama.

Rantung, J., Mandey, J., \& Londa, V. (2014). "Peranan Pemberdayaan Kesejahteraan Keluarga (PKK) dalam Menggerakkan Partisipasi Masyarakat Desa”. Jurnal Administrasi Publik, 111.

Yanti, R.H, dkk (2019). "Pengaruh Regulasi Emosi Singel Mother terhadap penerimaan diri pada anak Se-Kecamatan Rumbai Kota Pekanbaru". KINERGARTEN: Journal of Islamic Early Childhood Educatio. Vol.2 No.1 ;35-57.

Yuliani, R. (2013). "Emosi negatif siswa kelas XI SMAN Sungai Limau". Jurnal Ilmiah Konseling, 2(1): 151-155. 